\title{
Rectal injury during radical prostatectomy
}

\author{
Radikal prostatektomi sirasında rektal yaralanma
}

\author{
Mehmet YILDIRIM, ${ }^{1}$ Cemal GÖKTAŞ, ${ }^{2}$ Rahim HORUZ, ${ }^{2}$ Cihangir A. ÇETINEL, ${ }^{2}$ \\ Önder CANGÜVEN, ${ }^{2}$ Hasan Fehmi KÜÇÜK, ${ }^{1}$ Selami ALBAYRAK ${ }^{2}$
}

\section{BACKGROUND}

We evaluated the data of our patients who experienced rectal injury during radical prostatectomy (RP).

\section{METHODS}

We analyzed the data for the 7 patients (6 perineal, 1 retropubic) with iatrogenic rectal injury who were selected from 451 patients with RP (218 retropubic, 233 perineal) operated in our clinic between 2003 and 2011.

\section{RESULTS}

The mean age of the 7 patients was 64.4 years. Rectal injury occurred during prostatic apical dissection in 4 patients, during dissection of Denonvilliers fascia in 1 patient, during transection of the rectourethral muscles in 1 patient, and during dissection of the rectal region proximal to the anal sphincter in 1 patient. The mean size of the lesions was $2(1-4) \mathrm{cm}$. All of the rectal injuries were recognized during the operation, and double-layered sutures were used for the primary repair. None of the cases required colostomy procedure. No postoperative complications were encountered in 6 of the patients; however, 1 patient underwent a second operation on the following day due to detachment at the injury site. None of the patients displayed urethrorectal fistula, urinary incontinence or urethral stricture.

\section{CONCLUSION}

Primary repair with double-layered suturing is sufficient for the treatment of rectal injuries that occur during RP if they are recognized intraoperatively.

Key Words: Cancers; injuries; prostatectomy; rectal; urologic.

\section{AMAÇ}

Radikal prostatektomi (RP) sırasında iyatrojenik rektal yaralanma gelişen hastaların verileri değerlendirildi.

\section{GEREÇ VE YÖNTEM}

2003 ile 2011 y1llar1 arasında ameliyat edilen 451 RP (218 retropubik, 233 perineal RP) olgusu arasında, ameliyat s1rasında rektal yaralanma gelişen 7 hastanın (6 perineal, 1 retropubik RP) pre-, intra- ve post-operatif döneme ait klinik verileri geriye dönük olarak incelendi.

\section{BULGULAR}

Yedi hastanın ortalama yaşı 64,4 yıl idi. Rektal yaralanmanın, 4 hastada prostatın apikal diseksiyonu sirasında, 1 hastada Denonvillier fasyasinın diseksiyonu sırasında, 1 hastada rektoüretral kasların kesilmesi sırasında, 1 hastada ise anal sfinkterin hemen yakınındaki seviyede rektum diseksiyonu yapılırken geliştiği tespit edildi. Rektal yaralanmanın ortalama ebatı $2(1-4) \mathrm{cm}$ idi. Tüm olgularda yaralanan bölge anında fark edilerek çift-tabaka dikiş ile primer olarak perioperatif onarıldı, hiçbir olguda kolostomi uygulanmadı. Altı olguda ameliyat sonrası dönemde herhangi bir komplikasyonla karşılaşılmadı. Bir olguda ise yaralanan ve onarılan rektum duvarında gelişen detaşman nedeniyle ameliyattan sonra 1. günde cerrahi gerekti ve hasta sorunsuz iyileşti. Ameliyat sonrası takipte hiçbir hastada üretrorektal fistül, idrar inkontinansı veya üretral darlık ile karşılaşılmadı.

\section{SONUÇ}

Radikal prostatektomi sırasında fark edilmesi durumunda, rektum yaralanmalarının tedavisinde çift-tabaka dikiş ile primer onarım uygulanması yeterli olmaktadır.

Anahtar Sözcükler: Kanser; yaralanma; prostatektomi; rektal; ürolojik. 
Radical prostatectomy is the most effective method for the treatment of localized prostate cancer. The first technique that was described for prostatectomy was radical perineal prostatectomy, but retropubic radical prostatectomy has been the preferred surgical technique in the treatment of patients with localized prostate cancer disease since its introduction in the 1980s. More recently, laparoscopic and robotic retropubic techniques have been developed. Regardless of the surgical technique used, iatrogenic rectal trauma remains an important potential complication during prostatectomy.

In this study, we evaluated the data from patients in whom iatrogenic rectal injury occurred during radical prostatectomy.

\section{MATERIALS AND METHODS}

Seven patients who encountered iatrogenic rectal injury during radical prostatectomy were selected for this study from a population of 451 patients with localized prostate cancer (218 retropubic, 233 perineal radical prostatectomies) who were operated in our clinic between May 2003 and May 2011.

We recorded the clinical, operative and pathological data. In addition, preoperative (i.e., age, medical history, particular history of previous operations related to the rectum and/or prostate, body mass index (BMI), findings of digital rectal examinations (DREs), prostate-specific antigen (PSA) levels, biopsy findings, time between biopsy and the operation, and the clinical stage), intraoperative (i.e., the weight of the prostate and seminal vesicles as determined by measurements of the surgical specimens, the exact localization and size of the rectal injury, and the treatment of the injury), and postoperative (i.e., the Gleason score and the surgical margin status of the tumor, the time that oral alimentation was initiated, the time with a transurethral catheter, the treatment outcomes, and related complications) data were comparatively analyzed.

\section{RESULTS}

Among 7 patients with a mean age of 64.4 (56-70) years, radical perineal prostatectomy was performed in 6 patients, and retropubic prostatectomy was performed in 1 patient. None of the patients had a history of prostate or rectal surgery or radiotherapy. In 1 of the patients, there was a history of hospitalization with a diagnosis of acute prostatitis 30 years ago, which was treated with medication.

Four patients had a normal DRE, but we detected regional hardness in 2 patients and palpable nodules in 1 patient. The mean BMI was 27.4 (23.8-30.3).

The mean PSA value was $9.2(5.2-21.7) \mathrm{ng} / \mathrm{ml}$. The mean ratio of positive cores in the biopsies was $29.4 \%$ (10-66\%), and the mean duration between the date of the biopsy and the operation was 36 (16-52) days. All of the patients fasted for 8-12 hours (h) before the operation and were given $1 \mathrm{~g}$ of cefazolin intravenously for prophylaxis. One patient had an American Society of Anesthesiology (ASA) score of 3, 2 patients had an ASA score of 2, and 2 patients had an ASA score of 1. The mean operation time was 138 (115-165) minutes (min).

The mean weight of the surgical specimens (i.e., prostate and seminal vesicles) was 57.4 (40-74) g. Rectal injury occurred during prostatic apical dissection in 4 patients, during dissection of Denonvilliers fascia in 1 patient, during transection of the rectourethral muscles in 1 patient, and during dissection of the rectal region proximal to the anal sphincter in 1 patient. The mean size of the lesions was $2(1-4) \mathrm{cm}$. In 2 of the 4 patients with rectal injury during apical dissection, the pathology report revealed surgical margin positivity in the apical region of the prostate. The surgical margins were negative in the other 5 patients.

When the patients were evaluated according to the TNM classifications of prostate cancer that were published in 2009, the pathological stage was pT2a (the tumor involves one- half of 1 lobe or less) in 2 patients, pT2c (the tumor involves both lobes) in 2 patients, and pT3a (extracapsular extension including microscopic bladder neck involvement) in 3 of the patients. All of the rectal injuries were recognized during the operation, and double-layered sutures were used for the primary repair. Patients were placed on a liquid diet $24 \mathrm{~h}$ after the operation and given broad-spectrum antibiotic therapy ( $1 \mathrm{~g}$ cefazolin, $160 \mathrm{mg}$ gentamicin, $500 \mathrm{mg}$ metronidazole, all intravenously). In 6 of the patients, no complications were encountered during the postoperative period, and a normal diet was started on the 5th postoperative day. Interestingly, suspicious fecal drainage through the perineal incision was observed in 1 patient. He immediately underwent another operation, and a detachment was identified on the sutured rectal wall, which was previously injured and had been repaired. This site was repaired again with double-layered sutures, and the patient was able to tolerate a normal diet on the 5th postoperative day without any complications. No urethrorectal fistula was observed in any of the patients. In addition, urological follow-up of our cases did not reveal any instances of urinary incontinence or urethral stricture. The data of the patients are given in Table 1.

\section{DISCUSSION}

Radical prostatectomy is the most commonly used treatment method in localized prostate cancer because of its high oncological success. In addition to 
Table 1. Patient data

\begin{tabular}{|c|c|c|c|c|c|c|c|c|c|c|c|c|c|}
\hline No & A & $\mathrm{B}$ & $\mathrm{C}$ & $\mathrm{D}$ & $\mathrm{E}$ & $\mathrm{F}$ & G & $\mathrm{H}$ & I & $\mathrm{J}$ & $\mathrm{K}$ & $\mathrm{L}$ & M \\
\hline 1 & $\begin{array}{l}\text { Hardness } \\
\text { on the left } \\
\text { side }\end{array}$ & 5.3 & 38 & $1 / 10(10 \%)$ & pT2a $3+3$ & Negative & 74 & 2 & Dissection of Denonvilliers fascia & 6 & 16 & Primary repair & Cure \\
\hline 2 & Normal & 6.1 & 37 & $2 / 10(20 \%)$ & pT2a $4+3$ & Negative & 63 & 1 & Level of rectourethral muscles & 6 & 19 & Primary repair & Cure \\
\hline 3 & $\begin{array}{l}\text { Hard- } \\
\text { ness on the } \\
\text { right side }\end{array}$ & 21.7 & 26 & $4 / 6(66 \%)$ & pT $2 \mathrm{c} 3+4$ & Negative & 56 & 1 & Proximal to the anal sphincter & 9 & 16 & Primary repair & Cure \\
\hline 4 & Normal & 10.2 & 41 & $3 / 12(25 \%)$ & pT3a $3+3$ & Positive & 61 & 2 & Apical dissection & 13 & 30 & Primary repair & $*$ \\
\hline 5 & $\begin{array}{l}\text { Basal } \\
\text { nodule on } \\
\text { the right } \\
\text { side }\end{array}$ & 5.2 & 52 & $4 / 10(40 \%)$ & pT3a $3+3$ & Negative & 41 & 2 & Apical dissection & 7 & 20 & Primary repair & Cure \\
\hline 6 & Normal & 5.2 & 42 & $2 / 10(20 \%)$ & pT3a $3+3$ & Positive & 40 & 2 & Apical dissection & 6 & 14 & Primary repair & Cure \\
\hline 7 & Normal & 9.5 & 16 & $3 / 12(25 \%)$ & $\mathrm{pT} 2 \mathrm{c} 3+3$ & Negative & 67 & 4 & Apical dissection & 6 & 16 & Primary repair & Cure \\
\hline
\end{tabular}

A: DRE (Findings obtained upon digital rectal examination of the prostate); B: PSA ( $\mathrm{Ng} / \mathrm{ml}$ ); C: Time between biopsy and the operation (days); D: Ratio of positive cores obtained from the biopsy; E: Pathological stage (TNM) and Gleason score; F: Surgical margin positivity; G: Prostate weight (g); H: Size of the injury (cm); I: Time / localization of the injury; J: Hospitalization (days); K: Duration of transurethral catheter insertion (days); L: Treatment; M: Outcome; *: Re-repair on the 1st postoperative day and cure.

the open surgical methods, laparoscopic and robotic radical prostatectomy techniques are currently being performed with increasing frequency, and technical improvements are constantly being made.

One of the most important intraoperative complications in radical prostatectomy is rectal injury because of the anatomic relationship between the prostate and the rectum. Although the frequency of rectal injury in radical prostatectomy varies from $0 \%$ to $11 \%$ in the literature, ${ }^{[1,2]}$ it was reported to be as high as $28 \%$ in a review of the studies of cases of salvage prostatectomy. ${ }^{[3]}$ Importantly, there has been a decrease in the rate of rectal injury during radical prostatectomy operations in recent years, which may be due to the more refined surgical techniques and increasing anatomical knowledge of the male pelvis. ${ }^{[4]}$ Previous studies have suggested that the rates of rectal injury are higher when the surgeon is unfamiliar with radical prostatectomy. Indeed, Heinzer et al. ${ }^{[5]}$ reported a rectal injury rate of $2 \%$ among patients who were operated upon later in the study compared with $7.8 \%$ in the group of patients who were operated upon at the beginning of the study. Similarly, Castello et al. ${ }^{[6]}$ reported an $8 \%$ rectal injury rate in patients operated upon during the period when surgeons were still familiarizing themselves with the technique of radical prostatectomy.

It is difficult to conclude whether the rates of rectal injury vary from one technique to another in radical prostatectomy. In a comparative study, open retropubic radical prostatectomy and laparoscopic radical prostatectomy were found to have similar rectal injury rates (i.e., approximately $2.8 \%$ ). ${ }^{[7]}$ Another study that compared retropubic and perineal radical prostatectomy reported that rectal injury was more likely with the perineal approach. ${ }^{[8]}$ Similarly, the present study, which had a similar number of patients in each group (218 retropubic vs. 231 perineal), found that rectal in- jury was more frequent among perineal patients. Although the difference was not found statistically significant ( $\mathrm{p}=0.071)$, out of a total of seven patients with rectal injury, six were perineal and one was retropubic.

McLaren et al..$^{[9]}$ found that a history of radiotherapy or prostatic or rectal surgery predisposed patients to rectal injury, whereas the local stage of the disease did not. In contrast, several studies failed to find an increased risk in cases with a history of open prostatic adenomectomy or transurethral resection. ${ }^{[10,11]}$ A novel technique was reported in a study by Albayrak et al., ${ }^{[12]}$ and they recommended a circular incision of the bladder neck by endoscopic means to make the dissection of the bladder neck easier during perineal radical prostatectomy in cases with a previous history of prostatic surgery. Since none of our seven cases had a history of prostatic surgery, we did not use this technique; however, it may be helpful in decreasing the risk of rectal injury during radical prostatectomy in those cases with a history of prostatic surgery.

Iatrogenic rectal injuries may occur more frequently during salvage radical prostatectomy performed for a PSA recurrence after primary radiotherapy, brachytherapy, high-intensity focused ultrasound (HIFU), or cryotherapy. The increased incidence of iatrogenic rectal injuries in salvage radical prostatectomy cases is correlated with the local stage of the disease and associated with severe periprostatic fibrotic changes, which result from previous therapeutic procedures. ${ }^{[13-15]}$

Because the diagnosis of prostate cancer requires a transrectal biopsy, it is thought that a time interval of at least one month between the biopsy and the prostatectomy may have positive effects on the operation by enhancing the chances of resolving inflammation of the rectal wall and the prostatic/periprostatic tissues. A one-month waiting period between the biopsy and the operation might result in an easier dissection on 
the plane between the prostate and the rectum, which would decrease the risk of rectal injury. In the present study, the mean interval between the biopsy and the operation was 36 days, and the minimum interval was 16 days ( 1 case).

In the $1990 \mathrm{~s}$, preoperative bowel preparation was widely used before radical prostatectomy operations to obviate the need for colostomy in the case of rectal injury. ${ }^{[9]}$ Today, preoperative bowel preparation is generally not preferred. We did not require any gastrointestinal preparation other than a routine $8-12-\mathrm{h}$ preoperative fast, and this did not increase the need for colostomy.

Double-layered suturing is usually sufficient for the successful repair of rectal injuries occurring during radical prostatectomy. In most cases, the addition of a colostomy procedure would not be necessary after primary repair of the rectal wall. In general, colostomy may be necessary in certain cases with larger defects, intraoperatively unrecognized defects, fistula development, or in salvage radical prostatectomy procedures. $[1,6,13,16,17]$

There is a consensus among most authors about the importance of recognizing rectal injuries during the operation. The presence of a defect in the rectal wall may be tested by checking for a loss of gas through the rectal wall. This can be done by filling the operation area with isotonic saline and observing the saline after the injection of normal room air through the anus into the rectal lumen with a syringe. This test is only performed when rectal trauma is suspected. In all of our cases, the rectal trauma was recognized at the moment of the trauma and appropriately repaired during the same operative session. Simultaneous primary repair with double-layered suturing was sufficient in six cases, and no complications were encountered during the postoperative period of these six patients. In the remaining patient, however, a second operation was required after the development of fecal drainage from the operation site despite the primary repair. In the secondary operation, which was performed via the perineal approach on the first postoperative day, a 2 -cm detachment of the sutures on the rectal wall was closed with double-layered suturing, and no additional measure was needed. Drainage was resolved after the operation, and no complications were encountered. None of the patients required a colostomy procedure. We believe that the perineal approach has an advantage with respect to surgical exposure in the repair of rectal traumas. Patients who experience a rectal injury during laparoscopic radical prostatectomy may require open surgery and colostomy when it is not possible to repair the injury laparoscopically. ${ }^{[18,19]}$

In cases of iatrogenic rectal injury during radi- cal prostatectomy, complications can be observed postoperatively if the injury is not recognized during the operation. The most important complications are urorectal fistulas, peritonitis, infections related to the operation site, anastomotic strictures, and urinary incontinence. ${ }^{[6,9,20]}$ Previous studies have shown that unrecognized traumas resulting from the use of thermal energy, electrical energy or cautery, especially in laparoscopic surgery, are particularly vulnerable to fistula development. ${ }^{[6]}$ McLaren et al. ${ }^{[9]}$ reported the development of rectourethral fistulas in four out of 27 cases of rectal injury in which rectal trauma had been recognized and repaired intraoperatively. In addition, Fichtner et al. ${ }^{[20]}$ reported the development of fistulas in four out of 22 cases of intraoperatively recognized and repaired rectal trauma, and three patients required a colostomy procedure. Interestingly, Castillo et al. ${ }^{[6]}$ followed three patients with intraoperatively unrecognized trauma for one month using an indwelling transurethral catheter. Although the fistula disappeared in one of the cases, surgical repair of the fistula was necessary in the remaining two patients.

The majority of the published reports suggest that there is no need to limit the oral alimentation of patients if an effective primary repair is performed on the injured rectal wall. In the present study, the patients were permitted to start a liquid diet $24 \mathrm{~h}$ after the operation, and they tolerated a normal diet on the 5 th postoperative day.

In conclusion, primary repair with double-layered suturing is sufficient for the treatment of rectal injury that occurs during radical prostatectomy operations if it is recognized intraoperatively. Because radical prostatectomy operations might be complicated by fistulas and peritonitis, however, iatrogenic rectal injuries should always be considered as a potential complication of every radical prostatectomy operation.

\section{REFERENCES}

1. Kheterpal E, Bhandari A, Siddiqui S, Pokala N, Peabody J, Menon M. Management of rectal injury during robotic radical prostatectomy. Urology 2011;77:976-9.

2. Boeckmann W, Jakse G. Management of rectal injury during perineal prostatectomy. Urol Int 1995;55:147-9.

3. Rigaud J, Tiguert R, Fradet Y, Bouchot O. Salvage radical prostatectomy after radiotherapy failure in localized prostatic cancer. Prog Urol 2002;12:1179-87. [Abstract]

4. Schraudenbach P, Bermejo CE. Management of the complications of radical prostatectomy. Curr Urol Rep 2007;8:197202.

5. Heinzer H, Graefen M, Noldus J, Hammerer P, Huland H. Early complication of anatomical radical retropubic prostatectomy: lessons from a single-center experience. Urol Int 1997;59:30-3

6. Castillo OA, Bodden E, Vitagliano G. Management of rectal injury during laparoscopic radical prostatectomy. Int Braz J Urol 2006;32:428-33.

7. Artibani W, Grosso G, Novara G, Pecoraro G, Sidoti O, Sarti 
A, et al. Is laparoscopic radical prostatectomy better than traditional retropubic radical prostatectomy? An analysis of peri-operative morbidity in two contemporary series in Italy. Eur Urol 2003;44:401-6.

8. Lance RS, Freidrichs PA, Kane C, Powell CR, Pulos E, Moul JW, et al. A comparison of radical retropubic with perineal prostatectomy for localized prostate cancer within the Uniformed Services Urology Research Group. BJU Int 2001;87:61-5.

9. McLaren RH, Barrett DM, Zincke H. Rectal injury occurring at radical retropubic prostatectomy for prostate cancer: etiology and treatment. Urology 1993;42:401-5.

10. Elder JS, Gibbons RP, Correa RJ Jr, Brannen GE. Morbidity of radical perineal prostatectomy following transurethral resection of the prostate. J Urol 1984;132:55-7.

11. Ramon J, Rossignol G, Leandri P, Gautier JR. Morbidity of radical retropubic prostatectomy following previous prostate resection. J Surg Oncol 1994;55:14-9.

12. Albayrak S, Canguven O, Aydemir H, Goktas C, Cetinel C, Akca O. Endoscope-assisted radical perineal prostatectomy. J Endourol 2010;24:527-30.

13. Ahallal Y, Shariat SF, Chade DC, Mazzola C, Reuter VE, Sandhu JS, et al. Pilot study of salvage laparoscopic prostatectomy for the treatment of recurrent prostate cancer. BJU Int 2011;108:724-8.
14. Gotto GT, Yunis LH, Vora K, Eastham JA, Scardino PT, Rabbani F. Impact of prior prostate radiation on complications after radical prostatectomy. J Urol 2010;184:136-42.

15. Lawrentschuk N, Finelli A, Van der Kwast TH, Ryan P, Bolton DM, Fleshner NE, et al. Salvage radical prostatectomy following primary high intensity focused ultrasound for treatment of prostate cancer. J Urol 2011;185:862-8.

16. Borland RN, Walsh PC. The management of rectal injury during radical retropubic prostatectomy. J Urol 1992;147:905-7.

17. Guillonneau B, Gupta R, El Fettouh H, Cathelineau X, Baumert H, Vallancien G. Laparoscopic [correction of laproscopic] management of rectal injury during laparoscopic [correction of laproscopic] radical prostatectomy. J Urol 2003;169:1694-6.

18. Ou YC, Yang CR, Wang J, Yang CK, Cheng CL, Patel VR, et al. The learning curve for reducing complications of roboticassisted laparoscopic radical prostatectomy by a single surgeon. BJU Int 2011;108:420-5.

19. Chun L, Abbas MA. Rectourethral fistula following laparoscopic radical prostatectomy. Tech Coloproctol 2011;15:297300.

20. Fichtner J, Gillitzer R, Melchior SW, Hohenfellner M, Thüroff JW. Perineal complications following radical perineal prostatectomy. Aktuelle Urol 2003;34:223-5. 